\title{
The Impact of corporate governance on profitability of conventional banks operating in Pakistan
}

\author{
Hafiz Muhammad Naveed ${ }^{\mathrm{a}, *}$, Shoaib Ali ${ }^{\mathrm{b}}$ Yao Hongxing ${ }^{\mathrm{a}}$, Saqib Altaf ${ }^{\mathrm{b}}$, Jan Muhammad Sohu ${ }^{\mathrm{b}}$ \\ ${ }^{a}$ School of Finance and Economics, Jiangsu University, Zhenjiang 212013, China \\ ${ }^{b}$ School of Management, Jiangsu University, Zhenjiang 212013, China
}

\begin{abstract}
The key purpose of present research study to examine the association among corporate governance and profitability banks in developing counties. For such primary objective, annually based data collected from 2004 to 2016. The data taken from annual financial reports which issued by conventional banks. We have used ADF (Augmented Dickey Fuller) test to examine the unitroot of variables. Moreover, the multiple linear regression utilized for hypothetical estimation. The results indicates that corporate governance and conventional banks profitability of Pakistan are bidirectional (positive-negative) associated to each other. In addition, the board size (Board Directors) is negatively associated with Return on assets and return on equity of banks. Similarly, the board independence (Insider-Outsider Board Directors) is positively influenced to return on assets and return on equity of conventional banks of Pakistan. The overall findings shows that board size and board independence are highly associated with return on equity than return on assets. Moreover, banking sector in developing countries the board size should contain on appropriate strength and acquire more professional and qualified staff. An optimal number of directors in a board size there is a need of commercial banks as to increase the profitability. To enhance the investors' confidence with the bank there is also a need of the commercial banks to increases the board independency.
\end{abstract}

\section{Introduction}

The main purpose of this research to examine how the corporate governance is influenced to conventional banks profitability among the developing countries. The financial sector has an immense importance in blooming economy. This is inter-related with economic growth of a country. It is sheer impossible to attain economic development without effective functioning of financial sector. In the financial sectors, the banks especially commercial/conventional banks have fundamental role and keep key contributing in the national economy. The banking sector is working in the business sector as blood in the human body. We cannot deny the importance of conventional banks from business sector. Every financial investor is associated with banking sector directly-indirectly. However, banks is a place where people deposit our most liquid financial assets and accomplished the loans for investments perspective and others services. Most probably the banks get deposit on low rate of interest but give loans on high rate of interest. The margin between two rates of interest makes the profit for banks which obligatory for banks integrity. It executes its functions efficiently and effectively at every level so we cannot contradict the significance of banking sector in advancement of the economy (Levine, 2005). The major parts of the economy contains on the banking sectors and it bring optimal utilization of financial resources and best allocation. In the developed-developing countries, the conventional banks are provide sound quality services. Honestly speaking the Pakistan is a developing state where has numerous economic-noneconomic problems especially for baking sector.

\footnotetext{
* Corresponding author.

E-mail address: hafiznaveed778@gmail.com (Hafiz Muhammad Naveed)
} 
There had banks experienced interruption since the time of departure and faced obstacles in various areas including funds, trained human resource and economic and political instability. Haque and Tariq (2012), explained that the following fundamental activities to elevate banks efficiency, to make sure the political instability and make sound policies and for prolong time, to minimize constrains by central bank for conventional banks.

Moreover, the corporate governance is a group of experts that make the rules and regulations to operate the organization successfully. In addition, the corporate governance is a key mechanism which makes the policies that improve the organization health and protect the shareholder interest. The trust is very obligation between lenders and investors. So the solid and authentic policies to enhance the trust level between investor and lender. The trust level also consolidate whenever the investor return the borrowed money on the exact agreement date and time. Similarly, the economic position of a country can be also optimistic due to best corporate governance system (Aguilera \& Jackson, 2010). The bad governance are faced various type of agencies obstacles which high risky for integrity of organization and traced problem for entrepreneurs (Core, 2001). In addition, most often the complications arises between owners and managers due the misunderstanding or conflict of interest inside the organization. In the same way, the conflict of interests between minority shareholders and controlling shareholders is also among major corporate governance issues. The corporate governance is most significant for uplift the economic position. Due to bad governance in the developing countries are facing numerous problems. Pakistan is a growing/developing country where has many governance problems. The State Bank of Pakistan (Central Bank) started an appropriate project in March 2002 to improve the institutional governance. The fundamental terminology of this typical project was the investor whose willing for financing, they must be invest their money in those institutions on priority bases where have sound governance system. The bad corporate governance institutions will more struggle for upgrading to governance system due to definancializing. The prosperous corporate administration frameworks promote the improvement of strong financial development system that they are the bank or market based on positive effect on economic growth and poverty reduction.

For the hypothetical testing, we are using descriptive statistics for examine whether empirical data set is normal distributed or not. Moreover, the Augmented Dickey Fuller (ADF) entertained to verify the unit-root in the model or the stationarity among the model. If the data is stationary it means that mean, variance and covariance are constant in the data. The present research study also taken correlation matrix approach to analyse the association among the endogenous and exogenous variables. The correlation matrix explained how much total effect of an exogenous variable on endogenous variable. However, the correlation estimation is the best technique to measure the individual total effect between endogenous and exogenous variables. Furthermore, we are applied multiple linear regression (MLR) model to examine the linear data set afterward the nature logarithm implication on the nonlinear data. The MLR model executes the per-unit effect and whole effect on endogenous variables due to exogenous variables. We are also used Durbin-Watson approach to diagnose the autocorrelation or serial-correlation problem among the typical model. The behind study is contained on following sections: the $2^{\text {nd }}$ section is consist on similar previous studies. In the chapter we do study previous literature and make overview the knowledge about our topic. This chapter also taken the inadequate/limitations among the previous studies and elaborate novel idea/innovation of the study. At the bottom of the chapter we explained the conceptual model and definition of the variables. Moreover, the $3^{\text {nd }}$ section contained on empirical methodology of the present research study. In this section we are discussed population and sample size of the study, research techniques and tool of the study and with detailed discussion about econometric-model among the study. Similarly, the $4^{\text {th }}$ section taken results and discussion. This unit undertaken the major, minor and extra findings. Finally the hypothesis verification are finished in this chapter whether our constructed hypothesis accepted or rejected. In $5^{\text {th }}$ section we are discussing conclusion and some recommendations of the study. Here we shall conclude that how corporate governance influence the bank's profitability in the developing countries.

\section{Literature Review}

Corporate governance is a mechanisms which contained on owners, internal-external shareholder, and board of directors. The corporate governance is also interconnected along with whose administrative board leadership, board size, executive and non-executive directors. The leadership structure differentiates the duties and authority of Chief executive officer (CEO) from that of chairman of the Board (Tricker \& Tricker, 2015). Pakistan is a developing country where has many bad governance issues which real obstacle for financing and national economic development. 
The securities and exchange commission of Pakistan (SECP) is a well reputed public sector institute. In 2002, the SECP was intervention in some serious financial issues and generate numeric number on the corporate governance performance especially to protect investors and their investment interest. In the first time was issued the Pakistan code of corporate governance for enhancing transparency and governance in order to ensure full disclosure of financial reporting of organizations for protection of investor's interests.

From the previous decade, several research scholars are trying to examine the real solution of agency obstacles for uplift the corporate governance (Caprio \& Levine, 2002; Laeven \& Levine, 2006). There are financial problems have everywhere especially developing countries. The multinational corporations as like world-com, Enron and several others reputed organizations are more worried about governance to attract especially investors and stakeholders (Giroud \& Mueller, 2011; Tian \& Twite, 2011). Banking sector in developing countries, the bad governance is a major issue. In developing countries, the banking sectors are disappointed especially for failure of the banking saving money system can have huge cost (G. Simpson (2004); T. W. Simpson, 2004). Moreover, the external governance and banks performance are highly associated with each other. The efficiency and transparency of banking zone can be uplift by the optimal governance performance. Similarly, the good governance can be attract to cross-border investors (Ali et al., 2020).

According to the Asian Development Bank, the corporate governance is a mechanism where optimal utilization of resources and grab the economic benefits to bring the financial strength. (Wescott (2000)) elaborated the corporate governance makes legislations, planes, strategies to manage the organization. The main agenda of all is secure the partners and generate profit. On the other hand, Corporate governance is an indirect instrument which reduces the organization and exchange costs which are caused by the managers when they act to their greatest advantage as opposed to working for the advantages of organization and its shareholders (J. Kidd \& F.-J. Richter, 2003; J. B. Kidd \& F.-J. Richter, 2003; Nielsen, 2000).

\section{H1: There is a significant relationship between corporate governance and bank's profitability.}

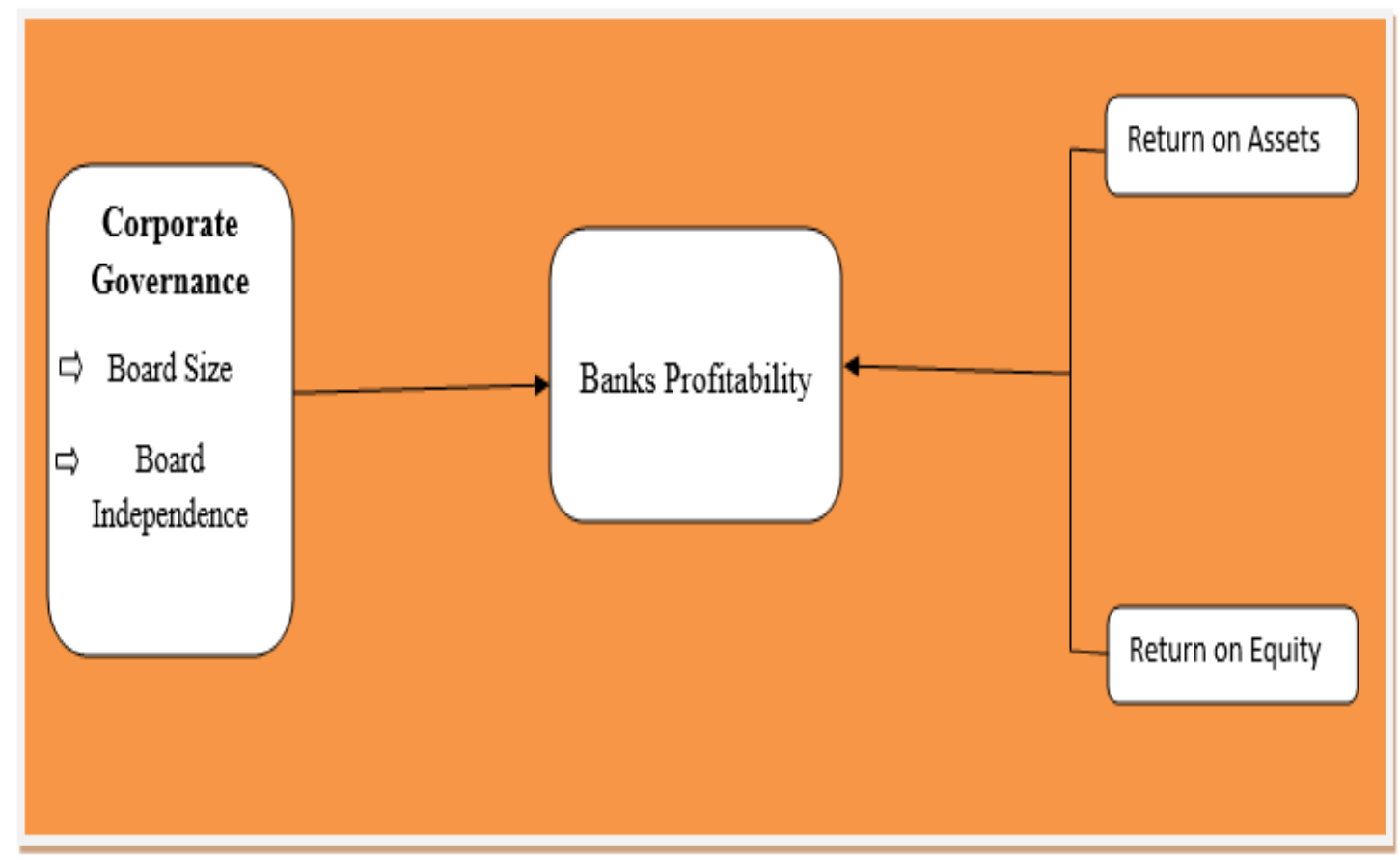

Fig. 1 Conceptual Model

In the above empirical model, the corporate governance taken as an exogenous variable which executed with board 
size (BDS) and board independence (BIND). Besides, banks profitability is taken as an endogenous variable which summarize with return on assets and return on equity.

Table.1 Definitions of the variables

\begin{tabular}{cl}
\hline $\begin{array}{c}\text { Variables } \\
\text { Endogenous Variables } \\
\text { Return on Assets } \\
\text { Return on Equity }\end{array}$ & $\begin{array}{c}\text { Description } \\
\text { Tet Income } \\
\text { Exogenous Variables } \\
\text { Board Size } \\
\text { Board Independence }\end{array}$ \\
\hline
\end{tabular}

3. Empirical Methodology

\subsection{Population and Sample Size}

This study examines the impact of Corporate Governance on profitability of conventional banks of developing countries. The population should be vivid before sample selection. The population of this research study is five key conventional banks of Pakistan. Moreover, the empirical data collected from the annual reports issued by banks which started from 2004 to 2019. The banks list is given below:

- Bank Alfalah

- United bank limited

- Allied bank limited

- Habib bank

- Muslim Commercial bank.

\subsection{Augmented Dickey Fuller Test}

The unit root estimation is used to check the stationary properties of the study variables. Stationery variable is defined as if the mean, variance and auto covariance of the variable will be same although it is determine on any level of point it has no concern. According to the econometric assumption, the variation among the data over the time should be constant. If the variation is constant then the empirical data would be upon stationary otherwise not. So upwarddownward variation in empirical data should be constant. Augmented Dickey Fuller (ADF) approach is validated to identify the problem concerning non-stationary/unit-root among the data. The father funder of this approach is (Dickey \& Fuller, 1981). The stationarity/ unit-root certification as follows:

$$
\Delta y_{t}=\alpha+\delta y t-1+\sum_{i=1}^{n} \gamma_{i} \Delta y_{t-1}+\varepsilon t
$$

whereas:

Here $y$ is an endogenous-exogenous variable variation with over the time. Moreover, $\alpha$ is intercept, and $t$ indicate the linear time trend (trend, trend $\&$ intercept and none), $\delta$ is the slope of y at one period lag over the time. Sigma shows that the total change the slope due to variation in y after one period lag. Furthermore, $\varepsilon_{t}$ is the stochastic error term. Here we are constructed hypothesis to test for unit-root. We can write as follows:

H0: $\delta=0$ if data has unit-root/non-stationary

H1: $\delta<0$ if data has no unit-root/stationary 


\subsection{Multiple Linear Regression Model}

The multiple linear regression (MLR) model used to examine the association among profitability of banks and corporate governance. The MLR model is very well-known and validated econometric model for the prediction of linear relationship of the variables. However, the empirical MLR model does exclude the biasness and detect to heterogeneity problem among the variables/cross the sample of the study. The model can be summarize as follows:

$$
y_{i t}=\alpha+\beta_{1} x_{i t}+\beta_{2} x_{i t}+\cdots+\beta_{n} x_{n}+\varepsilon_{i t}
$$

whereas:

$\mathrm{y}_{\mathrm{it}}=$ denotes to endogenous variable (return on assets and return on equity for bank) at time $\mathrm{t}$.

$\alpha=$ Intercept

$\beta=$ Slope of variable

$e_{\text {it }}=$ Stochastic Error Term

\section{Results and Discussion}

Table 2 Descriptive Statistics

\begin{tabular}{lllllccccc}
\hline \multirow{2}{*}{ Variables } & \multicolumn{2}{c}{ No. } & Minimum & Maximum & Mean & $\begin{array}{c}\text { Std. } \\
\text { Deviation }\end{array}$ & \multicolumn{2}{c}{ Skewness } & \multicolumn{2}{c}{ Kurtosis } \\
& Statistic & Statistic & Statistic & Statistic & Statistic & Statistic & Std.Error & Statistic & Std.Error \\
\hline ROA & 15 & 1.52 & 2.53 & 1.86 & 0.28182 & 1.137 & 0.637 & 1.886 & 1.232 \\
ROE & 15 & 25.75 & 32.42 & 29.35 & 2.07434 & -0.051 & 0.637 & -0.635 & 1.232 \\
BDS & 15 & 8.2 & 9.01 & 8.625 & 0.30488 & -0.123 & 0.637 & -1.472 & 1.232 \\
BIND & 15 & 7.01 & 8.40 & 7.8 & 0.48804 & -0.434 & 0.637 & -1.317 & 1.232 \\
\hline
\end{tabular}

Table 2 shows that the descriptive statistics of the overall model. We are examine the normality of empirical data via stat-model. In this model, we have some endogenous-exogenous variable (ROA, ROE, BDS \& BIND). In this model have fifteen number of observations, minimum-maximum, mean, standard deviation, skewness and kurtosis values. The statistic values of skewness and kurtosis indicates that our data is normalized.

Table 3 Unit Root Test

\begin{tabular}{ccccccc}
\hline & \multicolumn{3}{c}{ Level } & \multicolumn{3}{c}{ First Difference } \\
\cline { 2 - 6 } Variables & Intercept & $\begin{array}{c}\text { Trend and } \\
\text { Intercept }\end{array}$ & None & Intercept & $\begin{array}{c}\text { Trend and } \\
\text { Intercept }\end{array}$ & None \\
\cline { 2 - 6 } & 1.663189 & $4.298071^{*}$ & 0.652419 & 4.587892 & $4.591288^{*}$ & $4.816023^{*}$ \\
BIND & $1.32331^{* *}$ & 3.5197 & 1.410339 & $4.791230^{*}$ & $4.996902^{*}$ & $4.240741^{*}$ \\
BDS & $2.115231^{*}$ & 1.858494 & 0.036802 & $3.986821^{*}$ & $3.837356^{*}$ & $4.255132^{*}$ \\
ROA & $2.333343^{* * *}$ & 2.300944 & 0.09822 & $3.490655^{*}$ & 3.279093 & $3.790456^{*}$ \\
ROE & Note: *,* and *** denote $1 \%, 5 \%$ and $10 \%$ level of significance respectively. &
\end{tabular}

The Augmented Dickey Fuller is a further approach of statistical Unite Root Test order of integration. The 
Augmented Dickey Fuller test has applied to confirm the stationary level of the variables. Here we are taking meaning of stationary that whether the mean, variance and covariance statistics of the variables are constant or not. In addition, if these stat-values are not constant/variation then we must be use nature logarithm to bring the consistency of variation otherwise our results considered spurious. With respect econometric assumptions the output indicates that the all variables has no unit-root. In addition, ROA, ROE and BDS have become stationary on intercept at level. But the BIND has become stationary on trend $\&$ intercept at $1^{\text {st }}$ difference.

Table 4 Correlation matrix

\begin{tabular}{cccccc}
\hline Variables & Model & ROA & ROE & BDS & BIND \\
\hline ROA & & 1 & $.709^{* *}$ & $-.698^{* *}$ & $.710^{* *}$ \\
ROE & $\begin{array}{c}\text { Pearson } \\
\text { BDS }\end{array}$ & Correlation & 1 & $-.715^{* *}$ & $.771^{* *}$ \\
BIND & & 1 & $-.782^{* *}$ \\
Note: * and ** association is significant at 5\% \& 10\% (2-tailed). & & 1 \\
\hline
\end{tabular}

Note: * and ** association is significant at 5\% \& 10\% (2-tailed).

Table 4 shows the association among the endogenous and exogenous variables. The association-ship are examining on $5 \%$ and $10 \%$ level. The output indicates that the variables are correlated with each other. The whole variables highly associated at $10 \%$ level. ROE and BIND are highly associated than ROE and BDS.

Table.5 Coefficients

\begin{tabular}{cccccc}
\hline \multirow{2}{*}{ Model } & \multicolumn{2}{c}{$\begin{array}{c}\text { Unstandardized } \\
\text { Coefficients }\end{array}$} & $\begin{array}{c}\text { Standardized } \\
\text { Coefficients }\end{array}$ & t & Sig. \\
\cline { 2 - 4 } & B & Std. Error & Beta & & \\
\hline (Constant) & -3.704 & 1.807 & & -2.05 & 0.068 \\
BDS & -0.645 & 0.209 & -0.698 & -3.081 & 0.012 \\
BIND & 0.41 & 0.129 & 0.71 & 3.193 & 0.01 \\
\hline
\end{tabular}

Note: Endogenous Variable $=\mathrm{ROA} ; \mathrm{R}$ square $=0.71 ; \mathrm{F}=\mathrm{p}<0.05 ; \mathrm{DW}=1.141$

In table 5, examines the individual impact and overall impact of exogenous variables on endogenous variable. This table taking to ROA as an endogenous variable and BDS and BIND as exogenous variables. In this econometric model, the $t$ and $p$ values both are power of the model. The $t>2$ and $p<0.05$ which shows that there is significant relationship among the endogenous and exogenous variable. The unstandardized coefficient values of BDS \& BIND are $0.645 \& 0.41$ that indicate if one unit variation in BDS and BIND it become 0.645 \& 0.41 unit variation in ROA respectively. In addition, but overall variation in ROA is $71 \%$ due to BDS and BIND in conventional Banks of Pakistan. Furthermore, the DW value indicate that the stat-model is free from the problem of autocorrelation or serialcorrelation. 
Table 6 Coefficients

\begin{tabular}{llllll}
\hline \multirow{2}{*}{ Model } & \multicolumn{2}{c}{ Unstandardized Coefficients } & $\begin{array}{c}\text { Standardized } \\
\text { Coefficients }\end{array}$ & \multirow{2}{*}{ t } & Sig. \\
\cline { 2 - 4 } & B & Std. Error & Beta & & \\
\hline (Constant) & -12.581 & 12.989 & & -0.969 & 0.356 \\
BDS & -4.862 & 1.505 & -0.715 & -3.23 & 0.009 \\
BIND & 3.278 & 0.856 & 0.771 & 3.831 & 0.003 \\
\hline
\end{tabular}

Note: Endogenous Variable=ROE; R square $=0.771 ; \mathrm{F}=\mathrm{p}<0.05 ; \mathrm{DW}=1.625$

Table.6 is examining the hypothetical authentication which was created for variables association. In this econometric model, the ROE is an endogenous variable and BDS and BIND are exogenous variable. The $t$ and $p$ values are considered most significant statistic especial for accepted or rejected the model. The above table shows that the $\mathrm{t}>2$ and $p<0.05$ which evidence of relationship of the variables. The coefficient values elaborated that 4.862, 3.278 units variation in ROE due to only 1 unit change in BDS and BIND respectively. There has positive relationship between ROE and BDS, BIND. The $\mathrm{R}^{2}$ value shows that overall $77.1 \%$ change has come in ROE due BDS and BIND collectively. On the other hand, the DW value shows that there has no autocorrelation among the variables.

\section{Conclusion and Recommendations}

Two indicators of corporate governance mechanism are incorporated in this study (Board Size, and Board Independence) and data were obtained from the annual reports of the commercial banks. The literature review results are mixed in this study; however board size has a significant impact on the commercial bank profitability. Majority of the review related theories results shows small board size perform well in the commercial bank performance. The hypothesis shows that there is a significant relationship between the board size and commercial bank profitability. The board independence has a significant and positive impact on the commercial banks profitability. The Board independence means the number of outside directors presents in a board. From the results of the literature theories shows that the number of outside directors in board increase the bank's profitability will also increases. There is a significant relationship exists between the board independence and the commercial banks profitability. In Pakistan, the banking sectors is not out-performed from many previous decades due to the deterioration of the good corporate governance practice.

In this study, the overall regression results have shown a positive relationship between board size and board independence with the commercial banks profitability in Pakistan. However, board size and the board independence show the positive relationship between profitability ratios (ROA, ROE). The commercial banks should increase the non-executive (independent) directors in a board of directors so as to increases the commercial banks profitability. As a conclusion in this current study, the profitability of commercial banks must depends an optimal number of nonexecutive (independent) directors in a board. The current study recommends that after the above arguments, in developing countries the banking sector board size should not be too large and must be professional and more qualified. An optimal number of directors in a board size there is a need of commercial banks as to increase the profitability. To enhance the investors' confidence with the bank there is also a need of the commercial banks to increases the board independency.

Furthermore, the purpose of every investor on his investment to obtain maximum profit, they should target those banks with a good corporate governance practices. Maximization of shareholders wealth, by the attention of formulation and implementation of good corporate governance practices in institution. There is a need for the state bank of Pakistan (SBP) to enforce commercial banks corporate governance practices ownership and control for the profitability of commercial banks. Through the decision making, bank independency and transparency too become strong the CEO Chairperson of the boards and helps to ensure the sport of the interests. This concept brought awareness to the investors and general public in the market. There is a need for the state bank of Pakistan (SBP) to 
increases supervision on the commercial banks to the enhancement of bank sustainability and safety. Pakistan banking model should be improved in the future bank profitability.

\section{Acknowledgements}

We are accepted overall comments and suggestions by all anonymous reviewers. We are thankful to all reviews for commentarial contribution for improve the quality of this research study. This research study never be accomplished without excellent contribution of them. This study also thankful to all authors' co-authors who have participated in this study.

\section{References}

Aguilera, R. V., \& Jackson, G. (2010). Comparative and international corporate governance. Academy of Management annals, 4(1), 485-556.

Ali, S., Naveed. H. M., \& Khaliq.A. (2020). Does an External Governance Framework Enhance the Performance of Pakistan's Banking Sectors? Foreign Ownership as Moderator. Economy,

Vol. 7, No. 2, 110-118, 2020.

Caprio, G., \& Levine, R. (2002). Corporate governance in finance: Concepts and international observations. Financial sector governance: The roles of the public and private sectors, 17-50.

Core, J. E. (2001). A review of the empirical disclosure literature: discussion. Journal of accounting and economics, 31(1-3), 441-456.

Dickey, D. A., \& Fuller, W. A. (1981). Likelihood ratio statistics for autoregressive time series with a unit root. Econometrica: journal of the Econometric Society, 1057-1072.

Giroud, X., \& Mueller, H. M. (2011). Corporate governance, product market competition, and equity prices. The Journal of Finance, 66(2), 563-600.

Haque, A., \& Tariq, A. (2012). Efficiency of banks in Pakistan: A non parametric approach. Business and Economic Research, 2(1).

Kidd, J., \& Richter, F.-J. (2003). Corruption and governance in Asia: Springer.

Kidd, J. B., \& Richter, F.-J. (2003). The 'Oppression'of Governance? Corruption and governance in Asia (pp. 1-26): Springer.

Laeven, L., \& Levine, R. (2006). Corporate governance, regulation, and bank risk taking. World Bank Mimeo.

Levine, R. (2005). Finance and growth: theory and evidence. Handbook of economic growth, 1, 865-934.

Nielsen, J. D. (2000). The role of institutional investors in corporate governance. Dilemma, public lecture, Covenant University, Ota, Ogun State, January, 25.

Simpson, G. (2004). Great powers and outlaw states: unequal sovereigns in the international legal order (Vol. 32): Cambridge University Press.

Simpson, T. W. (2004). Product platform design and customization: Status and promise. Ai Edam, 18(1), 3-20.

Tian, G. Y., \& Twite, G. (2011). Corporate governance, external market discipline and firm productivity. Journal of Corporate Finance, 17(3), 403-417.

Tricker, R. B., \& Tricker, R. I. (2015). Corporate governance: Principles, policies, and practices: Oxford University Press, USA.

Wescott, C. (2000). Measuring governance in developing Asia. Paper presented at the Presentation Paper for the Seminar on International Experiences on Good Governance and Fighting Corruption, February. 